\title{
PRAWA WYBORCZE IMIGRANTÓW. REFLEKSJE NA TLE INSTYTUCJI OBYWATELSTWA EUROPEJSKIEGO
}

\section{Wstęp}

Prawo wyborcze, zarówno czynne jak i bierne, tradycyjnie wiązane jest z instytucją obywatelstwa. Relacja ta podlega jednak zmianom, m.in. pod wpływem procesów globalizacyjnych i wiążących się z nimi migracji międzynarodowych. Skala ruchów migracyjnych rodzi wyzwania dla współczesnego prawa wyborczego, a także dla samej demokracji. ${ }^{1}$

Przedmiotem niniejszego artykułu jest zagadnienie praw wyborczych w kontekście zjawisk migracyjnych w Unii Europejskiej, obszaru o długim i zróżnicowanym doświadczeniu migracyjnym, obszaru pozostającego stale atrakcyjnym miejscem docelowym imigracji z państw trzecich. Jednocześnie, Unię Europejską wyróżnia fundamentalne prawo do swobodnego przepływu osób. Uwzględniając powyższe, rozważania podjęte $\mathrm{w}$ niniejszym artykule obejmować będą prawa polityczne (w ujęciu zawężonym do praw wyborczych) imigrantów - obywateli państw trzecich, a także migrantów - obywateli państw członkowskich UE korzystających ze swobody przepływu osób. Rozróżnienie powyższe staje się konieczne i uwidacznia asymetrię rozwiązań w zakresie politycznej partycypacji² migrantów z UE i spoza niej.

1 T. Hammar, w swojej pracy „Democracy and the Nation State: Aliens, Denizens, and Citizens in a World of International Migration" (1990) postawił tezę, że istnienie dużej grupy imigrantów - wieloletnich rezydentów z dostępem do rynku pracy oraz świadczeń społecznych i socjalnych, jednak bez praw politycznych (tzw. denizens), która nie może decydować o kształcie polityki, może być szkodliwe dla demokracji; za: S. Łodziński, D. Pudzianowska, M. Szaranowicz-Kusz, Prawa wyborcze dla cudzoziemców - tak czy nie? Analiza procesu przyznawania praw wyborczych na poziomie lokalnym cudzoziemcom z państw trzecich w wybranych krajach Unii Europejskiej, Warszawa 2014, s. 9.

2 Jak słusznie zauważa M. Trojanowska-Strzęboszewska, posiadanie przez imigrantów praw politycznych nie może być całkowicie utożsamiane $z$ ich partycypacją polityczną; posiadanie określonych praw stanowi warunek partycypacji; za: M. Trojanowska-Strzęboszewska, Prawo do udziału w wyborach na szczeblu lokalnym jako forma partycypacji politycznej imigrantów. Polska na tle innych krajów europejskich, „Political Preferences” No. $7 / 2013$, s. 97. Uwzględniając powyższe, dalsze rozważania w artykule w zakresie przyznawania praw wyborczych dla imigrantów należy rozumieć jako jedną z przesłanek na rzecz zwiększania ich partycypacji politycznej. 
Polska, jako państwo członkowskie Unii Europejskiej, jest włączona w nurt wspomnianych procesów. Choć skala zjawisk migracyjnych w Polsce przemawia za koncentracją wokół zjawiska ożywionej - po wejściu Polski do UE - emigracji polskich obywateli, to konieczna dla dalszych rozważań staje się w tym miejscu zmiana optyki - podkreślenie, że także pod wpływem integracji z UE następuje w Polsce transformacja $\mathrm{z}$ typowego kraju emigracyjnego w kraj emigracyjno-imigracyjny a w świetle prognozowanego silnego spadku podaży pracy do 2060 r., szersze otwarcie na napływ imigrantów może stać się działaniem nieuniknionym. Stale jednak atrakcyjność Polski jako kraju docelowego ustępuje atrakcyjności tzw. „starych” państw członkowskich UE. Wyzwaniem w tym zakresie staje się zwiększenie tej atrakcyjności z uwzględnieniem działań na rzecz większej partycypacji politycznej imigrantów. Przyznanie czynnego i biernego prawa wyborczego stanowi wymowny wyraz nastawienia państwa przyjmującego wobec imigrantów. Nadto, warto zauważyć, że jest to rozwiązanie niekosztowne. ${ }^{3}$

\section{Obywatelstwo a prawa wyborcze w sensie podmiotowym}

Obywatelstwo to stosunek prawny, jaki łączy jednostkę z państwem. Z relacji jednostki z państwem wynikają prawa, prawa zastrzeżone dla obywateli tego państwa obejmujące wpływ na wybór władz. ${ }^{4}$ Obywatelstwo należy uznać za podstawową przesłankę posiadania praw wyborczych; wyjątki od tej zasady są rzadkie. ${ }^{5}$ Jednakże związek praw politycznych (w tym czynne i bierne prawo wyborcze) z instytucją obywatelstwa nie ma jednak charakteru koniecznego. O autonomiczności praw politycznych (w tym praw wyborczych w sensie podmiotowym) świadczy m.in. przyznawanie tego prawa osobom nie posiadającym obywatelstwa. Ciekawych przykładów dostarczają rozwiązania z różnych epok, a także współczesne relacje w zakresie obywatelstwo - prawa polityczne, odmienne w różnych krajach. Egzemplifikując, warto przytoczyć rozwiązania we francuskim imperium kolonialnym, gdzie w 1946 r. na mocy ustawy Lamine Guèye przyznano prawa wyborcze mieszkańcom kolonii francuskich bez nadawania im obywatelstwa. ${ }^{6} \mathrm{~W}$ świetle badań K. Groenendijka przeprowadzonych w 2008 r., siedemnaście państw (spośród 29 badanych państw europejskich) przyznało czynne prawo wyborcze określonym kategoriom cudzoziemców z państw trzecich w wyborach lokalnych. ${ }^{7}$

3 K. Groenendijk, Local Voting Rights for Non-Nationals in Europe: What We Know and What We Need to Learn, Bruksela 2008, s. 8.

4 A. Młynarska-Sobaczewska, Wolności i prawa człowieka i obywatela, (w:) D. Górecki (red.), Polskie Prawo Konstytucyjne, wyd. 4, Warszawa 2012, s. 86-87.

5 M. Jagielski, Prawo wyborcze, (w:) R. M. Małajny (red.), Polskie prawo konstytucyjne na tle porównawczym, Warszawa 2013, s. 259.

6 D. Pudzianowska, Obywatelstwo w procesie zmian, Warszawa, 2013, s. 76.

$7 \quad$ K. Groenendijk, Local Voting Rights..., op. cit., s. 3. 
Krąg osób uprawnionych do uczestnictwa w wyborach wywodzi się z zasady powszechności wyborów. Zasada ta została wypracowana w XIX w., kiedy to przyjmowano, że nie wszyscy mieszkańcy danego kraju powinni mieć prawo do wypowiadania się jako naród. W konsekwencji przyjęto starożytną koncepcję cenzusu obywatelskiego poprzez wyznaczenie kręgu podmiotów uprawnionych do uczestnictwa w życiu politycznym. ${ }^{8}$ Warto podkreślić, iż cenzus wyborczy jest rozumiany dwojako. Pod pojęciem tym rozumieć można, po pierwsze, każdy warunek uzależniający korzystanie przez jednostkę z podmiotowych praw wyborczych (jak cenzus płci, wykształcenia czy w ramach współczesnych cenzusów wyborczych: obywatelstwo, wiek, domicyl). Po drugie, cenzus wyborczy, w doktrynie, rozumiany jest jako dyskryminujące wyłączenie od podmiotowych praw wyborczych ze względu na brak wymaganych kwalifikacji (cech). Jednakże, zwolennicy tego poglądu cenzus obywatelstwa uznają za naturalne, niedyskryminujące wyłączenie, a nie cenzus wyborczy. ${ }^{9}$ Warto dodać, iż w opinii Europejskiej Komisji Praw Człowieka brak przyznania praw wyborczych dla cudzoziemców jest zgodny z pierwszym protokołem dodatkowym do Europejskiej Konwencji o ochronie praw człowieka i podstawowych wolności. ${ }^{10}$

\section{Obywatelstwo, prawa wyborcze a integracja europejska}

Instytucja obywatelstwa podlega dynamice pod wpływem rozwoju instrumentów prawa międzynarodowego ${ }^{11}$ czy pogłębiającej się integracji w ramach Unii Europejskiej. Na mocy Traktatu z Maastricht (art. G.C), ${ }^{12}$ wyznaczającego nowy etap w procesie tworzenia silniejszych związków między narodami państw członkowskich Unii, wprowadzono obywatelstwo Unii Europejskiej dla wszystkich obywateli jej państw członkowskich, w związku z czym nadano im szereg praw. Zgodnie ze zmianami wprowadzonymi przez Traktat z Maastricht do Traktatu ustanawiającego Wspólnotę Europejską (art. 8b), ${ }^{13}$ każdy obywatel Unii Europejskiej, zamieszkujący w państwie członkowskim, którego nie jest obywatelem ma prawo głosowania i kandydowania w wyborach lokalnych w państwie członkowskim, w którym dana osoba

8 M. Jagielski, Prawo..., op. cit., s. 257.

9 B. Michalak, A. Sokala, P. Uziębło, Leksykon prawa wyborczego i referendalnego oraz systemów wyborczych, Warszawa 2013, s. 26.

10 Artykuł trzeci pierwszego protokołu dodatkowego brzmi: „Wysokie Układające się Strony zobowiązują się organizować w rozsądnych odstępach czasu wolne wybory oparte na tajnym głosowaniu, w warunkach zapewniających swobodę wyrażania opinii ludności w wyborze ciała ustawodawczego"; (Protokół dodatkowy do Konwencji o ochronie praw człowieka i podstawowych wolności, Dz.U. z 1993 r. Nr 61, poz. 284).

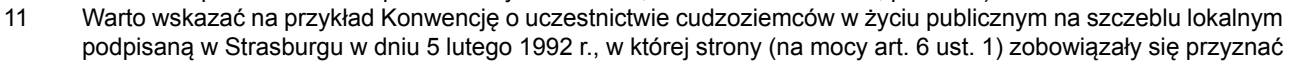
czynne i bierne prawo wyborcze w wyborach lokalnych cudzoziemcom legalnie i stale zamieszkującym terytorium tego państwa przez pięć lat; za: Convention on the Participation of Foreigners in Public Life at Local Level, „European Treaty Series”, no 144.

12 Treaty on European Union, Dz.Urz. UE 191 z 29.7.1992, s. 7.

13 Treaty establishing the European Community, Dz.Urz. UE 224 z 31.8.1992, s. 11. 
ma miejsce zamieszkania. Dodatkowo, na mocy art. 8b ust. 2 TWE, każdy obywatel Unii Europejskiej, zamieszkujący w państwie członkowskim, którego nie jest obywatelem uzyskał prawo głosowania i kandydowania w wyborach do Parlamentu Europejskiego, w państwie członkowskim, w którym ma miejsce zamieszkania.

Warto podkreślić, iż przyznanie czynnego i biernego prawa wyborczego dla obywateli państw członkowskich UE zamieszkujących inne państwo członkowskie, którego nie są obywatelami wiązane jest z prawem do swobodnego przemieszczania się i pobytu na terytorium państw członkowskich UE. Taką argumentację wskazuje Dyrektywa 94/80/WE. ${ }^{14}$ Słusznie uznano, że barierę dla migrujących obywateli UE (np. w celu wykonywania pracy) mogą stanowić ograniczone możliwości partycypacji w życiu społecznym i politycznym regionu zamieszkania. ${ }^{15}$

Konieczne staje się podkreślenie, iż argumentacja o braku praw politycznych jako bariery dla migracji nie stanowiła jednak przesłanki dla przyznania w prawie europejskim praw wyborczych dla imigrantów - obywateli państw trzecich. Jednocześnie, w latach 90. XX wieku dostrzeżono, że brak akceptacji dla aktywności politycznej cudzoziemców (obywateli państw trzecich) pozostaje w sprzeczności z wkładem imigrantów zarobkowych i wykorzystaniem ich potencjału na rynku pracy. ${ }^{16}$ Znaczna część państw europejskich podjęła debatę o możliwości przyznania praw wyborczych dla imigrantów, i jak sygnalizowano, prawo 16 państw członkowskich UE (i wybranych kantonów Szwajcarii) przewiduje takie uprawnienia dla imigrantów z państw trzecich. Taki kierunek zmian - przyznanie praw wyborczych dla obywateli $\mathrm{w}$ ramach ugrupowania integracyjnego, a następnie pozytywne zmiany w zakresie przyznawania praw wyborczych dla obywateli spoza ugrupowania, nasuwa naturalne porównanie do doświadczeń integracji nordyckiej.

\section{Prawa wyborcze migrantów w Polsce}

Jak już podniesiono, podstawową przesłanką posiadania praw wyborczych w Polsce jest obywatelstwo polskie. Jednakże, w związku z akcesją Polski do Unii

14 Dyrektywa 94/80/WE Rady z dnia 19 grudnia 1994 r. ustanawiająca szczegółowe warunki wykonywania prawa głosowania i kandydowania w wyborach lokalnych przez obywateli Unii mających miejsce zamieszkania w Państwie Członkowskim, którego nie są obywatelami (Dz.Urz. UE, L 368 z 31.12.1994, s. 3).

15 Jednakże, Dyrektywa przewiduje pewne ograniczenia - w przypadku biernego prawa wyborczego dozwolone jest wprowadzanie przez państwa członkowskie zastrzeżenia, że wyłącznie obywatele własnego państwa mogą być wybierani na stanowisko kierownika organu wykonawczego (art. 5 ust. 3 Dyrektywy). Nadto, zgodnie z Dyrektywą, państwo członkowskie może zażądać od osoby składającej wniosek o kandydowanie posiadającej obywatelstwo innego państwa członkowskiego oświadczenia (a nawet zaświadczenia z państwa pochodzenia) o braku pozbawienia go prawa do kandydowania w państwie członkowskim, którego jest obywatelem (art. 9 Dyrektywy). Analogicznie, w przypadku wykonywania biernego prawa wyborczego w wyborach do Parlamentu Europejskiego obywatel UE zobligowany jest do przedłożenia zaświadczenia potwierdzającego, że nie pozbawiono go prawa kandydowania w wyborach w państwie członkowskim jego pochodzenia; za: Dyrektywa 93/109/WE Rady z dnia 6 grudnia 1993 r. ustanawiająca szczegółowe warunki wykonywania prawa głosowania i kandydowania w wyborach do Parlamentu Europejskiego przez obywateli Unii mających miejsce zamieszkania w Państwie Członkowskim, którego nie są obywatelami (Dz.U. UE, L 329 z 30.12.1993, s. 7).

16 S. Łodziński, D. Pudzianowska, M. Szaranowicz-Kusz, Prawa wyborcze..., op. cit., s. 9. 
Europejskiej i koniecznością dostosowania prawa krajowego do acquis communautaire, konieczne stały się odstępstwa od powyższego. Przyznanie obywatelom innych państw członkowskich UE praw wyborczych w wyborach lokalnych rodziło pewne wątpliwości. Należy jednakże podkreślić, iż były to głównie zastrzeżenia natury prawnej, aniżeli obawy społeczne. Wyjaśnienie tego stanu rzeczy może leżeć w istniejącym wówczas przeświadczeniu o niskiej atrakcyjności Polski jako kraju docelowego migracji obywateli innych państw członkowskich UE, stąd czynnikiem stopującym możliwe zaniepokojenie społeczeństwa mogła być skala zjawiska. ${ }^{17,18}$

Odpowiedzią na wątpliwości natury konstytucyjnej w zakresie prawa obywateli innych państw członkowskich UE do udziału w wyborach lokalnych był wyrok Trybunału Konstytucyjnego z dnia 11 maja 2005 r. W wyroku tym Trybunał orzekł o braku niezgodności tego prawa z Konstytucją RP, uznając, że prawa wyborcze w wyborach lokalnych przysługujące obywatelom innych państw członkowskich „nie zagrażają Rzeczypospolitej Polskiej jako dobru wspólnemu wszystkich obywateli, z uwagi na konstytucyjnie określony charakter wspólnot samorządowych oraz nałożone na nie zadania i przyznane w związku z tym kompetencje". ${ }^{19}$

Trybunał Konstytucyjny odniósł się także do zarzutu, iż przyznanie czynnego i biernego prawa wyborczego obywatelom Unii Europejskiej niebędącym obywatelami polskimi stanowi naruszenie art. 4 ust. 1 Konstytucji wyrażającego zasadę suwerenności Narodu i w swym wyroku (z 31 maja 2004 r. $)^{20}$ uznał, iż prawo to nie jest niezgodne $\mathrm{z}$ Konstytucją RP, podkreślając jednocześnie, iż zastąpienie cenzusu obywatelstwa państwowego cenzusem domicylu wiąże się z ustanowieniem obywatelstwa europejskiego.

Należy zauważyć, iż na kanwie argumentacji Trybunału Konstytucyjnego w wyroku z dnia 11 maja 2005 r. - o braku zagrożenia dla niepodległości Polski w związku z przyznaniem praw wyborczych dla obywateli innych państw członkowskich UE w wyborach lokalnych - ze względu na charakter wspólnot samorzą-

17 Argument ten potwierdza np. fakt, iż w wyborach do Parlamentu Europejskiego przeprowadzonych w 2014 r. w Polsce, na prawie 30,6 mln wyborców (ujętych w spisach) jedynie 340 wyborców stanowili obywatele innych państw członkowskich UE; za: Sprawozdanie z wyborów do Parlamentu Europejskiego przeprowadzonych w dniu 25 maja 2014 r., Państwowa Komisja Wyborcza, Warszawa 2014, s. 8. W przypadku wyborów lokalnych przeprowadzonych w Polsce w 2014 r. wśród 30,5 mln wyborców jedynie 637 stanowili obywatele UE niebędący obywatelami polskimi; za: Dane statystyczne dotyczące wyborów do rad oraz w wyborach wójtów, burmistrzów i prezydentów miast zarządzonych na dzień 16 listopada 2014 r. http://pkw.gov.pl/obwieszczenia-i-komunikatysamorzad-2014/informacje-statystyczne-na-temat-wyborow.html (data dostępu: 08.01.2015 r.).

18 Warto także podkreślić znacznie ograniczoną ówcześnie świadomość praw wynikających z obywatelstwa unijnego wśród obywateli polskich. Badania przeprowadzone w listopadzie 2007 r. wykazały, iż zaledwie $31 \%$ respondentów z Polski wskazało na posiadanie przez obywatela innego państwa członkowskiego UE czynnego i biernego prawa wyborczego w wyborach lokalnych; jednocześnie zbliżona liczba respondentów wskazała niepoprawnie na posiadanie przez obywatela innego państwa członkowskiego czynnego i biernego prawa wyborczego w wyborach do parlamentu narodowego; za: Electoral rights of EU citizens. Analytical report. Flash Eurobarometer 292/2010, s. 8-9.

19 Wyrok TK z dnia 11 maja 2005 r. (Sygn. akt K 18/04), Wybrane orzeczenia Trybunału Konstytucyjnego związane z prawem Unii Europejskiej (2003-2014), „Studia i Materiały Trybunału Konstytucyjnego”, tom L, 2014, s. 137.

20 Wyrok TK z dnia 31 maja 2004 r. (Sygn. akt K 15/04), Wybrane orzeczenia Trybunału Konstytucyjnego związane z prawem Unii Europejskiej (2003-2014), „Studia i Materiały Trybunału Konstytucyjnego”, tom L, 2014, s. 63. 
dowych, w obrębie których nie mogą być podejmowane rozstrzygnięcia dotyczące całego państwa, rodzą się naturalne pytania o możliwości przyznania praw wyborczych w wyborach lokalnych w Polsce dla cudzoziemców z państw trzecich. Trybunał explicite podkreślił, że kryterium przynależności do wspólnoty samorządowej nie jest uzależnione od posiadania polskiego obywatelstwa, lecz od miejsca zamieszkania. Niestety, uznanie, iż wspólnota samorządowa stanowi wspólnotę mieszkańców, nie stanowiło dla polskiego ustawodawcy przesłanki dla przyznania praw wyborczych w wyborach lokalnych w Polsce dla cudzoziemców z państw trzecich. Brak takiego rozwiązania w literaturze jest przedmiotem krytyki. ${ }^{21}$

\section{Partycypacja polityczna imigrantów - argumenty za i przeciw}

Jak już podnoszono, prawa wyborcze tradycyjnie uznawane były za prawa przypisane jedynie obywatelom danego państwa. Pogląd, że tylko obywatele danego państwa powinni uczestniczyć w podejmowaniu decyzji politycznych stanowi jeden z głównych argumentów przeciw przyznawaniu praw wyborczych cudzoziemcom. Nadto, sprzeciw dla większej partycypacji politycznej imigrantów tłumaczony jest próbą zapobieżenia ryzyka wpływu ze strony obcych rządów, które mogą oddziaływać na procesy polityczne za sprawą swoich obywateli. Podnosi się również, iż przyznanie cudzoziemcom (czy bezpaństwowcom) praw wyborczych w wyborach lokalnych rodzi ryzyko wywołania efektu domina - traci wówczas na sile argument o nieprzyznawaniu praw wyborczych w wyborach krajowych..$^{22}$ Kolejny argument przeciw rozszerzaniu praw wyborczych na cudzoziemców dotyczy zagrożenia związanego z możliwością transmisji, przenoszenia przez imigrantów konfliktów politycznych z krajów ich pochodzenia. ${ }^{23}$ Należy w tym miejscu zauważyć, że część argumentów przeciw przyznaniu cudzoziemcom praw wyborczych zasadza się w określonych obawach, ryzykach, co może być implikowane samym stosunkiem do imigracji i cudzoziemców. Uznając jednak wartość dodaną migracji legalnych, korzyści, jakie niesie praca obcokrajowej siły roboczej o komplementarnym charakterze w stosunku do zatrudnienia krajowej siły roboczej, większość państw unijnych zdecydowała się na przyznanie - ograniczonych najczęściej do wyborów lokalnych - praw wyborczych cudzoziemcom spoza UE. Jakie argumenty legły u podstaw tych działań? Wśród argumentów uzasadniających przyznanie praw wyborczych cudzoziemcom warto podkreślić ten, na który wskazuje preambuła Konwencji o uczestnictwie cudzoziemców w życiu publicznym na szczeblu lokalnym. Podkreślone zostało, że na poziomie wspólnot lokalnych, cudzoziemcy przeważnie posiadają takie same

Por. np. P. Uziębło, Podstawowe prawa i wolności polityczne cudzoziemców w RP, (w:) M. Zdanowicz (red.), Status prawny cudzoziemca w Polsce, „Białostockie Studia Prawnicze” 2007, nr 2, s. 150.

K. Groenendijk, Local Voting Rights..., op. cit., s. 6. 
obowiązki, jak obywatele. ${ }^{24}$ Argumentem powiązanym z powyższym jest podnoszony pogląd, iż mieszkańcy wspólnoty regularnie płacący podatki, powinni być reprezentowani w organach decydujących m.in. o sposobie wydatkowania zgromadzonych środków, w myśl hasła kolonistów spod rządów Korony Brytyjskiej z XVIII w. „no taxation without representation” - nie dla opodatkowania bez reprezentacji. Uzasadnienie powyższe pozostaje w pewnej korelacji z następującą przesłanką: uzyskanie praw wyborczych przez cudzoziemców buduje ich poczucie odpowiedzialności za kraj przyjmujący, umożliwia im poczuć się ,,współgospodarzami”. ${ }^{25}$

Kolejnym istotnym argumentem, który trudno odpierać, w szczególności w ramach opartej o demokratyczne ideały Unii Europejskiej, jest kwestia wykluczenia imigrantów z demokracji, przy jednoczesnym wykorzystaniu ich potencjału. Wreszcie, uzasadnieniem na rzecz przyznania praw wyborczych dla cudzoziemców może być fakt, iż żadne państwo europejskie, które przyznało prawa wyborcze w wyborach lokalnych dla nie-obywateli nie zniosło tego prawa $\mathrm{z}$ powodu negatywnych konsekwencji, jakie to działanie może za sobą nieść. ${ }^{26}$

\section{Uwagi końcowe}

Mając świadomość, że powyższe rozważania nie wyczerpują zagadnienia inkluzji politycznej imigrantów w państwie przyjmującym, w drodze przyznania imigrantom praw wyborczych, poczynione refleksje, w zamyśle, mają stanowić impuls szerszej dyskusji, eksponującej racje przyznania imigrantom praw wyborczych. Jednakże, analiza odnosząca się do praw wyborczych imigrantów w Polsce, wskazująca $\mathrm{z}$ jednej strony na brak rozwiązań w zakresie przyznania praw wyborczych w wyborach lokalnych dla cudzoziemców z państw trzecich, a z drugiej strony na takie możliwości (brak przeszkód natury konstytucyjnej), stanowić ma nie tyle impuls do dyskusji o wyzwaniach, z jakimi zmierzyć musi się Polska w najbliższych latach, w kontekście przewidywanego zwiększonego zapotrzebowania na imigrację zarobkową w kraju w kolejnych latach. Warto w tym miejscu wyartykułować, że zmiany te nie mogą być odkładane na przyszłość. Argument o braku rozwiązań w zakresie praw wyborczych dla cudzoziemców w związku z niską obecnie - w porównaniu do innych krajów UE - skalą imigracji w Polsce, zdaje się nie wytrzymywać krytyki. Raz jeszcze warto podkreślić ograniczoną - na tle innych państw UE - atrakcyjność Polski jako państwa docelowego migracji. Jednym z działań zwiększających tę atrakcyjność, zachęcających do imigracji dających jasny wyraz nastawienia państwa przyjmującego do imigrantów może być przyznanie praw wyborczych dla cudzoziemców. W tym aspekcie, działania te muszą mieć charakter ex-ante. ries", no 144 .

25 http://blog.iom.pl/content/prawa-wyborcze-dla-cudzoziemc\%C3\%B3w-tak-czy-nie (data dostępu: 13.01 .2015 r.). 


\section{BIBLIOGRAFIA}

Electoral rights of EU citizens. Analytical report. Flash Eurobarometer 292/2010, European Commission, 2010

Groenendijk K., Local Voting Rights for Non-Nationals in Europe: What We Know and What We Need to Learn, Migration Policy Institute, 2008

Jagielski M., Prawo wyborcze, (w:) R. M. Małajny (red.), Polskie prawo konstytucyjne na tle porównawczym, Wydawnictwo C.H. BECK, Warszawa 2013

Łodziński S., Pudzianowska D., Szaranowicz-Kusz M., Prawa wyborcze dla cudzoziemców - tak czy nie? Analiza procesu przyznawania praw wyborczych na poziomie lokalnym cudzoziemcom z państw trzecich w wybranych krajach Unii Europejskiej, Międzynarodowa Organizacja do Spraw Migracji (IOM), Instytut Socjologii UW, Warszawa, 2014

Michalak B., Sokala A., Uziębło P., Leksykon prawa wyborczego i referendalnego oraz systemów wyborczych, Wolters Kluwer, Warszawa 2013

Młynarska - Sobaczewska A., Wolności i prawa człowieka i obywatela, (w:) D. Górecki (red.), Polskie Prawo Konstytucyjne, wyd. 4, Wolters Kluwer business, Warszawa 2012

Prawa wyborcze dla cudzoziemców - tak czy nie? http://blog.iom.pl/content/ prawa-wyborcze-dla-cudzoziemc\%C3\%B3w-tak-czy-nie

Pudzianowska D., Obywatelstwo w procesie zmian, Wolters Kluwer, Warszawa, 2013

Sprawozdanie z wyborów do Parlamentu Europejskiego przeprowadzonych w dniu 25 maja 2014 r., Państwowa Komisja Wyborcza, Warszawa, 2014

Trojanowska-Strzęboszewska M., Prawo do udziału w wyborach na szczeblu lokalnym jako forma partycypacji politycznej imigrantów. Polska na tle innych krajów europejskich, Political Preferences No. 7/2013.

Uziębło P., Podstawowe prawa i wolności polityczne cudzoziemców w RP, (w:) M. Zdanowicz (red.), Status prawny cudzoziemca w Polsce, „Białostockie Studia Prawnicze” 2007, nr 2 


\section{VOTING RIGHTS FOR IMMIGRANTS. REFLECTIONS ON THE BACKGROUND OF EU CITIZENSHIP}

Voting rights are traditionally associated with the institution of citizenship. This relationship, however, is subjected to change, i.e. under the influence of globalization and international migration. The scope of migration flows raise challenges for modern electoral law as well as for democracy itself. The subject of this article is the issue of voting rights in the context of the migration phenomenon in the European Union. The considerations in this article include the voting rights of immigrants (third-country nationals and migrants) and citizens of EU member states within the framework of free movement of persons. This distinction becomes necessary and highlights asymmetric solutions for the political participation of immigrants from the EU and beyond.

Keywords: migrants, voting rights, European Union

Słowa kluczowe: migranci, prawa wyborcze, Unia Europejska 